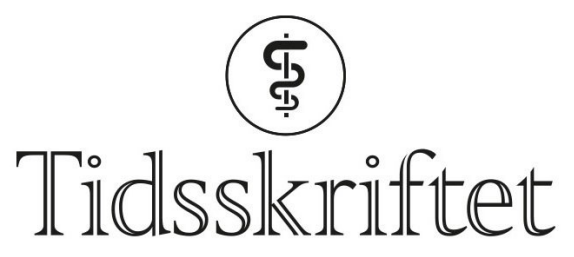

DEN NORSKE LEGEFORENING

\title{
Toeggede tvillinger etter innsetting av ett embryo
}

MEDISINEN I BILDER

\section{HANS IVAR HANEVIK}

E-post: hanhan@sthf.no

Hans Ivar Hanevik (f. 1978) er ph.d., overlege og medisinsk ansvarlig ved Fertilitetsavdelingen Sør, Sykehuset Telemark, Porsgrunn.

Forfatteren har fylt ut ICMJE-skjemaet og oppgir ingen interessekonflikter

\section{ASTRID HELENE SYDTVEIT}

Astrid Helene Sydtveit (f. 1983) er bioingeniør ved Fertilitetsavdelingen Sør, Sykehuset Telemark, Porsgrunn.

Forfatteren har fylt ut ICMJE-skjemaet og oppgir ingen interessekonflikter

\section{ERLING EKERHOVD}

Erling Ekerhovd (f. 1958) er dr.med., spesialist i fødselshjelp og kvinnesykdommer og overlege ved Fertilitetsavdelingen Sør, Sykehuset Telemark, Porsgrunn.

Forfatteren har fylt ut ICMJE-skjemaet og oppgir ingen interessekonflikter

En kvinne i midten av 3o-årene og hennes partner var til in vitro-fertilisering (IVF) på grunn av primær infertilitet. Etter vanlig utredning fant man ingen sikker forklaring på parets barnløshet, bortsett fra at kvinnen i perioder hadde uregelmessige menstruasjonsintervaller og at sædkvaliteten var moderat redusert.

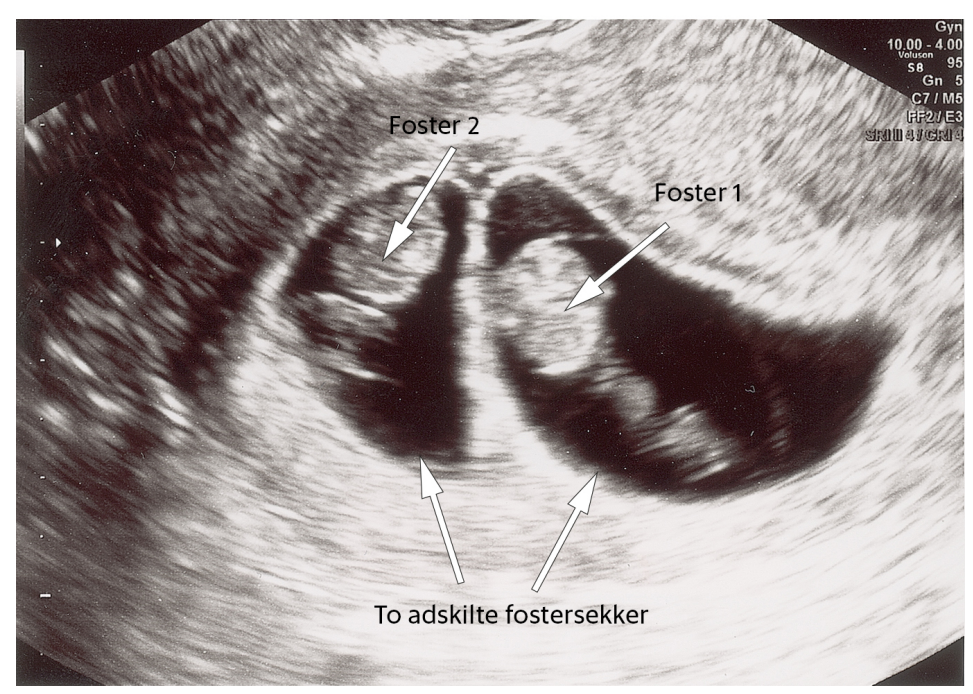

Kvinnen ble ikke gravid ved det første forsøket på in vitro-fertilisering. Ett overtallig embryo 
ble imidlertid fryst ned, og det ble bestemt at man skulle benytte dette embryoet ved neste forsøk.

Ved frysefors $ø$ ket ble kvinnen behandlet med aromatasehemmeren letrozol for å fremme optimal eggløsning (1). Det ble utført transvaginal ultralydundersøkelse et par dager før forventet eggløsning, hvor man så to preovulatoriske follikler. Kvinnen fikk positiv eggløsningstest, og embryoet ble tint og satt inn i livmorhulen. Graviditetstesten et par uker senere var positiv. Paret kom derfor til ultralydundersøkelse i svangerskapsuke 8 . Både de blivende foreldrene og den undersøkende legen ble overrasket da man så to adskilte fostersekker, hver med ett vitalt foster. Som bildet viser forelå en diamnional, dikorial tvillinggraviditet.

En toegget tvillinggraviditet etter innsetting av ett embryo krever en forklaring. Det er i dag vanlig behandlingsstrategi å sette inn ett embryo ved in vitro-fertilisering, hvorpå overtallige embryoer blir fryst ned for å kunne benyttes senere. Forekomsten av tvillinggraviditeter etter innsetting av ett embryo er over $2 \%$. Hoveddelen av disse er eneggede tvillinger, men toeggede tvillinggraviditeter er ikke helt uvanlig (2).

I dette tilfellet hadde man altså sett to preovulatoriske eggposer på dag $11 \mathrm{i}$ menstruasjonssyklusen. Årsaken til tvillinggraviditeten er selvsagt at paret har hatt samleie. Riktignok viste gjentatte sædprøver noe redusert kvalitet, men dette utelukker ikke naturlig konsepsjon. Vi kan ikke vite om den ene graviditeten skyldes innsetting av et tinet embryo i livmorhulen, eller om hvert av eggene i de to eggposene resulterte i graviditet.

Hvordan gikk det så med svangerskapet? Ved ballonginduksjon på grunn av preeklampsi i svangerskapsuke 35 oppsto en kraftig vaginalblødning. Man kunne ikke utelukke placentaløsning. Det ble derfor utført keisersnitt, og to barn, en jente og en gutt, kom til verden.

\section{LITTERATUR:}

1. Ekerhovd E. Ovulasjonsinduksjon ved bruk av letrozol. Tidsskr Nor Legeforen 20o9; 129: 412 - 5 . [PubMed][CrossRef]

2. Osianlis T, Rombauts L, Gabbe M et al. Incidence and zygosity of twin births following transfers using a single fresh or frozen embryo. Hum Reprod 2014; 29: 1438 - 43. [PubMed][CrossRef]

Publisert: 19. mars 2018. Tidsskr Nor Legeforen. DOI: 10.4045/tidsskr.17.0565 Mottatt 29.6.2017, første revisjon innsendt 8.12.2017, godkjent 15.1.2018.

(C) Tidsskrift for Den norske legeforening 2020. Lastet ned fra tidsskriftet.no 